\title{
Challenges of Participatory Approach to Watershed Management in Rural Communities of Enugu State
}

\author{
Enwelu, 1.A*.; Agwu, A.E. and Igbokwe, E.M. \\ Department of Agricultural Extension \\ University of Nigeria, Nsukka, Enugu State. \\ ${ }^{\star}$ E-mails: enwachonamin@yahoo.com \\ Mobile: +2348035090033
}

\begin{abstract}
The study highlights the status of existing watersheds management in four rural communities of Enugu State. Both qualitative and quantitative approaches (Rapid Rural Appraisal, focus group discussions, key informant interviews, and semistructured interview schedules) were used in an interactive manner to collect data for this study from four rural communities in the state. The study revealed that many problems such as fuel wood exploitation, farming activities, animal grazing/hunting, and road/house construction, among others were factors threatening the sustainability of watersheds in Enugu State. The study also showed that many of the communities had rules and regulations guiding the use of watersheds but could not apply the principle of participatory management approach to ensure sustainability of the watersheds. However, the rules and regulations merely emphasized environmental sanitation of the watershed surroundings without ensuring the overall sustainability of the watersheds. The paper concludes with the need for public and private extension services to educate key actors in rural communities on the sustainability of using participatory watershed management approach.
\end{abstract}

Key words: Sustainability, status, rules and regulations.

\section{Introduction}

Generally speaking, water is wrongly recognized as an inexhaustible commodity by people living in areas where there is plenty of it at the moment. According to Pitman (2002) water should be recognized as a scarce natural resource subject to many interdependencies in conveyance and use. Water is one of the most important of all natural resources. It is vital for all living organisms and major ecosystems as well as for human health, food production and economic development. Hence, access to water can be viewed as a human right issue because it is crucial for all aspects of human life (Sherbinin, 1997). However, it is becoming increasingly difficult to satisfy the collective thirst of people, industry and agriculture without damaging the world's limited resource of fresh water. The source of this fresh water is the watershed. The availability, quantity and quality of this precious but finite natural resource depend largely on its watershed [United State Environmental Protection Agency (U S EPA), 2003].

Watershed or the drainage area is the area that supplies water to a stream and its tributaries by direct runoff and by groundwater runoff (Douglas, Considine and Considine, 1989). Also, according to South Florida Water Management Department (SFWMD, 2004a), watershed is the area of land that drains into a body of water such as stream, lake, river or ocean which is separated from other watersheds by high points in the areas such as hills or slopes including not only the water ways itself but also the entire land area that drains to it. 
The present quest for development is undermining the sustainable use of natural resources. Development comes with benefits and problems. But unfortunately only the benefits are seen thereby giving room for the problems to grow and mature as it is today. Therefore, it has been argued that a major reason for our failure to conserve natural ecosystems is that we do not realize how valuable they are. Farmers deciding whether to burn a hectare of forest to clear it for agriculture focus on the potential yields they may obtain but pay little attention to the many ecological services (such as purification of air and water, regulation of rain water run-off and drought, water assimilation and detoxication, soil formation and maintenance, control of pests and diseases etc) that would go up in smoke. Likewise, ministers of finance of various countries, often base their budget decisions solely on the basis of indicators such as gross domestic product (GDP), foreign exchange balances and tax receipts in which ecosystem services either do not appear or are not recognized as such. Indeed, perversely GDP often identifies activities that destroy ecosystems as "benefits". No surprisingly, conservation budgets tend to get slighted if they appear at all (Achim, Stephen and lan, 2005).

These unsustainable activities are adversely affecting the environment. There is increasing evidence that the climate system is experiencing pronounced change with an increase of $0.6^{\circ} \mathrm{C}$ in the mean surface temperature of the planet since the end of nineteenth century [Intergovernmental Panel on Climate Change (IPCC, 2001)]. Similarly, land use changes are changing watershed landscape patterns, ecosystem functions and climate dynamics; they affect bio-diversity and hydrology and the transport of latent heat, carbon dioxide, nutrients and pollutants. Although global change is driven by nature, humans have become a significant environmental force with vast implications for watershed systems. Humans are not only subject to environmental change, but also constitute one of the main driving forces behind that change (Huber, Bugmann and Reasoner, 2005).

In some parts of eastern Nigerian states like Anambra and Enugu, a number of unsustainable activities are currently going on around the watersheds. For example in Anambra State, bush burning, logging, farming and uncontrolled erections of houses very close to the watersheds are generally visible. In the case of Enugu State, forest plantation is giving way to new houses and roads. The building of houses and construction of roads have led to the excessive excavation of sands and stones around the watersheds. These large stones/rocks protect the watersheds and once removed predispose the watersheds to destruction (Enwelu, 2007).

However, the earliest attempt to sustainable watershed management in Enugu State, was the preservation of some streams and rivers owned by gods/goddesses. The deities forbid the entry into the surrounding forests (watersheds) with the intention to collect fuel wood, fell trees or cut grasses. Also, fishing or killing of certain animals like python, tortoise, monkey etc were forbidden. In some streams or rivers, washing of clothes were not allowed at all while in some others bathing and washing were allowed only at designated locations (Enwelu, 2007).

As at present, a number of socio-economic, cultural, political, demographic, religious and environmental changes are continuously taking place to challenge the earlier fairly sustainable watershed management practices. However, one salient point remains, that in almost all the changes, human beings have played significant roles. Therefore to ameliorate the problems caused by these changes, human beings and their institutions must be fully and consciously involved. 
According to Sherbinin (1997) new approaches are urgently needed to manage watersheds rationally and equitably. Many useful studies have been conducted to assess the contribution of participatory watershed management approach (Turton, Coulter, Shah and Farnagton 1998; Kerr, Pangare and Pangare 2002; Joshi, Tewari, Jha and Shuyani 2003; Reddy, Reddy, Galab, Sousson and Baginski 2004 and Wani, Sing, Sreendevi, Pathak, Rego, Shiferaw and lyer 2005). These studies revealed that participatory watershed management projects have positive impact on crop productivity.

This study therefore raises the following research questions: What are the challenges to sustainability of watersheds in Enugu State? What are the challenges to sustainability of watershed rules and regulations in the various communities? Who are the agents of watershed management and maintenance?

\section{Purpose of the Study}

The main purpose of this study is to highlight the challenges of participatory approach to watershed management in rural communities of Enugu State. Specifically, the study sought to:

1. identify the challenges to sustainability of watershed in Enugu State;

2. ascertain the challenges to sustainability of watershed rules and regulations;

3. identify the agents of watershed management and maintenance; and

4. draw implications for participatory approach to watershed management.

\section{Methodology}

This study was conducted in rural communities of Enugu State, Nigeria. The state is traversed by many rivers, streams and springs namely Oji, Ozom, Mamu, Odu, Adada, Ekulu, lyi Uba, Asu, Atavo, Ufam, Nvene, Ezera, etc. The population for the study included all people living in the communities where the watersheds were located. Multistage sampling technique was used in obtaining sample for the study. Enugu State is made up of three senatorial zones namely Enugu East, Enugu West and Enugu North. However, Enugu East and Enugu West zones were randomly selected for the study.

Enugu East senatorial zone has five Local Government Areas (LGAs) likewise Enugu West, five LGAs. One LGA (Nkanu West) was randomly selected from Enugu East zone and another one LGA (Oji River) was also randomly selected from Enugu West zone. On the other hand, two communities were purposively selected from Nkanu West LGA namely Ozalla Nkanu and Akagbe Ugwu because of existence of Ufam and Nvene watersheds in Ozalla Nkanu and Akagbe Ugwu respectively. Similarly, two communities namely Achi-Agu and Oji Urban were purposively selected from Oji River LGA because of the existence of lyi-Owerre watershed at Achi-Agu (Ahani) and Ezera watershed at Mile 2 Oji Urban.

In each community with the assistance of village/ town development union and opinion leaders, a list of 100 heads of households was compiled based on villages/clans located near the watershed and/or that owned watershed resources. From the list 30 heads of households were randomly selected from each community giving a total sample size of 120 respondents. However, in Oji Urban and Achi-Agu 27 copies of the semi-structured interview schedule each were properly completed and returned while 22 and 24 copies were returned from Ozalla Nkanu and Akagbe Ugwu respectively. Hence, a total of 100 respondents were involved in the study. 
Both qualitative and quantitative methods were used in collecting data. Semistructured interview schedule based on the objectives were used to collect quantitative data. Rapid rural appraisal (RRA), focus group discussion (FGD) and key informant interviews were used in interactive manner to clarify ambiguous issues arising from the study. The perception of respondents with regard to the effectiveness of sanctions for violators of watershed rules and regulations was measured on three point Likert type scale and values were assigned thus: Very effective (3), effective (2) and not effective (1). These values were summed up to give 6 which was divided by 3 to give a mean score of 2 . Variables with mean scores of 2 and above were regarded as effective and variables with mean score below 2 were regarded as not effective. The data collected were analyzed using descriptive statistics.

\section{Results and Discussion \\ Challenges to Sustainability of Watershed in Enugu State}

Data in Table I show that all $(100.00 \%)$ the respondents in the four communities (Oji Urban, Achi- Agu, Ozalla- Nkanu and Akagbe, Ugwu) agreed that the following activities were going on around their watersheds: collection of fuel woods, farming activities, animal grazing and hunting of animals. In some of the communities especially in Oji Urban and Achi- Agu, the rate of fuel wood exploitation was so high that life trees were sometimes cut for fuel woods. In these communities, the sale of fuel woods had become a very lucrative business. The hike in prices of petroleum products is compounding the situation thereby forcing the already overstretched rural people to fall back to the natural resources (watersheds). The effects of this unsustainable exploitation on watersheds and the resultant climate change cannot be quantified. Farming activities were reported to be going on in all the communities. Land clearing/felling of trees, bush burning, mound making, fertilizer and herbicide application, chemical fishing etc associated with farming have disastrous consequences on watershed sustainability. Some of the nutrients can lead to eutrophication which is the process by which damaging quantities of nutrients accumulate in water bodies (Fleming, Hufschmidt and Hyman, 1982). This adversely affects the sustainability of watersheds now and in the long run.

All the communities $(100.00 \%)$ indicated that animals were grazing in their watersheds. The animals destroy the grasses and at times pollute the source of freshwater. This was a major source of conflict between the Fulani cattle rearers and some communities in Enugu State (Oji, Udi, Ezeagu and Nkanu). Animal hunting around the watershed was also observed in all the communities. The use of sophisticated guns in hunting posed a serious threat to endangered animal species facing extinction. The lack of some organisms in the food chain is indirectly affecting the animal population and a threat to sustainable watershed development.

Another unsustainably activity observed in some of the communities was sand/stone excavation found only in Oji Urban (100.00) and Akagbe Ugwu (87.50\%). The excavation activities were not witnessed around the watersheds in Achi- Agu $(0.00 \%)$ and Ozalla- Nkanu $(0.00 \%)$. In Oji Urban at Ezera watershed, the spring water had been adversely affected because of the massive felling of trees and shattering of large rocks that protect the water at the source with explosive dynamites. Excavation had also led to other unsustainable activities like construction of motor able roads to the sites, clearing of grasses and uprooting of trees etc. 
Consequently, the volume of Ezera spring water is decreasing year by year as the excavation continues.

Table 1: Percentage distribution of respondents' reported unsustainable activities going on around the watersheds in the communities

\begin{tabular}{|c|c|c|c|c|c|}
\hline \multirow{2}{*}{ On Going Activities* } & \multicolumn{4}{|c|}{ Watersheds/communities } & \multirow[b]{2}{*}{ 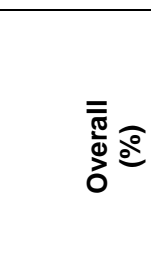 } \\
\hline & 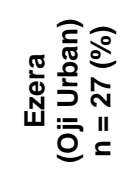 & 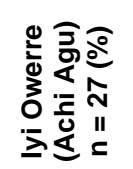 & 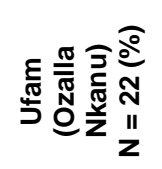 & 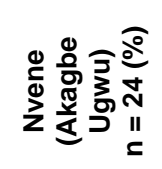 & \\
\hline Houses built close to the watersheds & 0.00 & 0.00 & 0.00 & 58.33 & 14.58 \\
\hline $\begin{array}{l}\text { Excavators collecting sands/stones } \\
\text { Collection of fuel woods } \\
\text { Farming activities }\end{array}$ & $\begin{array}{l}100.00 \\
100.00 \\
100.00\end{array}$ & $\begin{array}{l}0.00 \\
100.00 \\
100.00\end{array}$ & $\begin{array}{l}0.00 \\
100.00 \\
100.00\end{array}$ & $\begin{array}{l}87.50 \\
100.00 \\
100.00\end{array}$ & $\begin{array}{l}46.86 \\
100.00 \\
100.00\end{array}$ \\
\hline $\begin{array}{l}\text { Roads to the watersheds (motor able roads) } \\
\text { Felling of trees } \\
\text { Washing and bathing anywhere } \\
\text { People defecating and urinating around the } \\
\text { water shed }\end{array}$ & $\begin{array}{l}100.00 \\
100.00 \\
100.00 \\
100.00\end{array}$ & $\begin{array}{l}0.00 \\
14.81 \\
0.00 \\
25.9\end{array}$ & $\begin{array}{l}0.00 \\
18.18 \\
0.00 \\
22.92\end{array}$ & $\begin{array}{l}100.00 \\
50.00 \\
0.00 \\
41.67\end{array}$ & $\begin{array}{l}50 \\
45.75 \\
25 \\
47.62\end{array}$ \\
\hline $\begin{array}{l}\text { Natural fishing } \\
\text { Fishing with chemicals } \\
\text { Animal grazing } \\
\text { Hunting of animals }\end{array}$ & $\begin{array}{l}74.07 \\
92.59 \\
100.00 \\
100.00 \\
\end{array}$ & $\begin{array}{l}25.92 \\
0.00 \\
100.00 \\
100.00 \\
\end{array}$ & $\begin{array}{l}68.18 \\
72.73 \\
100.00 \\
100.00 \\
\end{array}$ & $\begin{array}{l}16.67 \\
0.00 \\
100.00 \\
100.00\end{array}$ & $\begin{array}{l}46.21 \\
41.33 \\
100.00 \\
100.00\end{array}$ \\
\hline
\end{tabular}

${ }^{*}$ Multiple responses

\section{Challenges of watershed rules and regulations in the communities}

Lack of watershed rules and regulations in these respects reveal the magnitude of un-sustainability of watersheds in these communities. Only a few number of respondents reported that they had such rules as: no setting of fire on watersheds $(32.80 \%)$; no fishing with chemicals $(36.53 \%)$ and no felling of trees $(38.08 \%)$. This is a potential threat to the sustainability of watersheds in these communities. On the contrary, rules and regulations like clearing the roads to the stream/river $(75.00 \%)$; cleaning the stream/river channel $(71.88 \%)$; washing of clothes/bathing at specified location $(75.00 \%)$; and no defecating/urinating around the river $(62.78 \%)$ were the ones operational in the communities. In this case, the communities had rules and regulations on cleanliness which were important for environmental sanitation of watershed surroundings but they could not ensure the overall sustainability of the watersheds. During the focused group discussion( FGD) it was discovered that the people saw watershed as an economic asset ready to be tapped and had no need for further investments. This basic assumption was the main reason behind unsustainable management of watersheds in the communities. This calls for watershed extension education and necessity for participatory watershed management approach.

Entries in Table 2 reveal that there were no existing rules and regulations in all the communities $(0.00 \%)$ in the following areas: farming/grazing of animals; 
excavation of sands/stones; building of houses very close to the watersheds; and fuel wood exploitation.

Table 2: Percentage distribution of watershed rules and regulations in the communities

\begin{tabular}{|c|c|c|c|c|c|}
\hline \multirow[b]{2}{*}{ Rules and Regulations* } & \multicolumn{4}{|c|}{ Watersheds/communities } & \multirow[b]{2}{*}{$\begin{array}{l}\text { Overall } \\
(\%)\end{array}$} \\
\hline & $\begin{array}{c}\text { Ezera } \\
\text { (Oji } \\
\text { Urban) } \\
\mathrm{n}=27 \\
(\%) \\
\end{array}$ & $\begin{array}{c}\text { lyi Owerre } \\
\text { (Achi Agu) } \\
\mathrm{n}=27 \\
(\%)\end{array}$ & $\begin{array}{c}\text { Ufam } \\
\text { (Ozalla } \\
\text { Nkanu) } \\
\mathrm{n}=22 \\
(\%)\end{array}$ & $\begin{array}{c}\text { Nvene } \\
\text { (Akagbe } \\
\text { Ugwu) } \\
\mathrm{n=24} \\
(\%)\end{array}$ & \\
\hline $\begin{array}{l}\text { Clearing of roads to the } \\
\text { stream/river }\end{array}$ & 0.00 & 100.00 & 100.00 & 100.00 & 75.00 \\
\hline $\begin{array}{l}\text { Cleaning the stream/river } \\
\text { channels and their surrounding }\end{array}$ & 0.00 & 100.00 & 100.00 & 87.5 & 71.88 \\
\hline $\begin{array}{l}\text { Washing of clothes/bathing at } \\
\text { specified locations }\end{array}$ & 0.00 & 100.00 & 100.00 & 100.00 & 75.00 \\
\hline $\begin{array}{l}\text { No defecating/urinating around } \\
\text { river }\end{array}$ & 0.00 & 85.19 & 90.91 & 75.00 & 62.78 \\
\hline $\begin{array}{l}\text { No excavation/or collection of } \\
\text { sands/stones }\end{array}$ & 0.00 & 0.00 & 0.00 & 0.00 & 0.00 \\
\hline No fishing with chemicals & 0.00 & 37.03 & 59.10 & 50.00 & 36.53 \\
\hline $\begin{array}{l}\text { No felling of trees around the } \\
\text { banks of the stream }\end{array}$ & 0.00 & 48.15 & 50.00 & 54.17 & 38.08 \\
\hline No farming/grazing of animals & 0.00 & 0.00 & 0.00 & 0.00 & 0.00 \\
\hline $\begin{array}{l}\text { No setting fire around the } \\
\text { watersheds }\end{array}$ & 0.00 & 44.44 & 40.91 & 45.83 & 32.80 \\
\hline No fuel wood exploitation & 0.00 & 0.00 & 0.00 & 0.00 & 0.00 \\
\hline $\begin{array}{l}\text { No building of houses around the } \\
\text { watersheds }\end{array}$ & 0.00 & 0.00 & 0.00 & 0.00 & 0.00 \\
\hline $\begin{array}{l}\text { Mature women not allowed to } \\
\text { wash clothes }\end{array}$ & 0.00 & 0.00 & 0.00 & 100.00 & 25.00 \\
\hline $\begin{array}{l}\text { Menstruating women not allowed } \\
\text { to wash hand/body }\end{array}$ & 0.00 & 0.00 & 0.00 & 100.00 & 25.00 \\
\hline $\begin{array}{l}\text { Widows not to fetch water until } \\
\text { after one year }\end{array}$ & 0.00 & 0.00 & 0.00 & 58.33 & 14.58 \\
\hline $\begin{array}{l}\text { No slippers/shoes allowed into } \\
\text { the stream }\end{array}$ & 0.00 & 100.00 & 0.00 & 0.00 & 25.00 \\
\hline $\begin{array}{l}\text { No widow/widower is allowed to } \\
\text { bath in the stream/river until after } \\
\text { one month }\end{array}$ & 0.00 & 0.00 & 68.18 & 0.00 & 17.05 \\
\hline $\begin{array}{l}\text { No washing or bathing before } \\
10.00 \text { am in the morning }\end{array}$ & 0.00 & 0.00 & 100.00 & 0.00 & 25.00 \\
\hline
\end{tabular}




\section{Effectiveness of Sanctions against Violators of Watershed Rules and Regulations}

Table 3 shows the mean distribution of respondents' perception of the effectiveness of sanctions against violators of watershed rules and regulations in the communities. Fines (2.25) were effective in all the communities except Oji Urban with practically no sanctions at all. Seizing of property of violators (1.84) was practised in three of the communities but was not effective. Also, the respondents perceived ostracism (0.19), prosecution in court/police (0.29) and use of idols (0.27) as not effective in three of the communities and not practised at all in Oji Urban. During the FGD it was clarified that the town community development unions in the three communities were against the use of such sanctions. Lack of town union in Oji Urban was probably responsible for no sanctions at all against violators in the community. The effectiveness of rules and regulations in ensuring sustainability of watersheds in the communities depended on the effectiveness of sanctions and where there were no rules and regulations, the sanctions were of no consequence. Here lies the need for participatory approach which will facilitate such action.

The lack of effective sanctions against violators of watershed rules and regulations in the watersheds promote such practices as felling of trees, excavation activities, fishing with chemicals, bush burning, and excessive exploitation of fuel woods etc., which lead to un-sustainability of watersheds. Again, the effective sanctions were only directed towards rules and regulations that emphasized the sanitation of watershed environment which had minimal effect on the sustainability of the watersheds (See Table 2).

Table 3: Mean distribution of respondents' perception of the effectiveness sanctions of watershed rules and regulations in the communities

\begin{tabular}{|c|c|c|c|c|c|}
\hline \multirow[b]{2}{*}{$\begin{array}{l}\text { Sanctions } \\
\text { Violators }\end{array}$} & \multicolumn{4}{|c|}{ Rating by watershed communities } & \multirow[b]{2}{*}{$\begin{array}{c}\text { Overall } \\
\qquad \bar{x}\end{array}$} \\
\hline & $\begin{array}{c}\text { Ezera } \\
\text { (Oji } \\
\text { Urban) } \\
\bar{x}\end{array}$ & $\begin{array}{c}\text { lyi Owerre } \\
\text { (Achi Agu) } \\
\bar{x}\end{array}$ & $\begin{array}{c}\text { Ufan } \\
\text { (Ozalla } \\
\text { Nkanu) } \\
\bar{x}\end{array}$ & $\begin{array}{c}\text { Nvene (Akagbe } \\
\text { Ugwu) } \\
\bar{x}\end{array}$ & \\
\hline Fines & 0.00 & 3.00 & 3.00 & 3.00 & 2.25 \\
\hline Ostracism & 0.00 & 0.30 & 0.23 & 0.23 & 0.19 \\
\hline $\begin{array}{l}\text { Prosecution in } \\
\text { court/police }\end{array}$ & 0.00 & 0.44 & 0.32 & 0.38 & 0.29 \\
\hline $\begin{array}{l}\text { Seizing of property of } \\
\text { violators }\end{array}$ & 0.00 & 2.53 & 2.44 & 2.38 & 1.84 \\
\hline $\begin{array}{l}\text { Use of idols or their } \\
\text { symbols }\end{array}$ & 0.00 & 0.37 & 0.30 & 0.42 & 0.27 \\
\hline
\end{tabular}

Agents of participatory watershed management and maintenance in the communities

Results in Table 4 and 5 show the major stakeholders for watershed management and maintenance. With the exception of Oji Urban which had no watershed management, other communities like Achi- Agu, Ozalla- Nkanu and Akagbe Ugwu had town community development unions as their major stakeholder 
in watershed management (Table 4). Youth and women organizations were also stakeholders in watershed management in the communities (Achi- Agu $40.74 \%$ and 33.33\%; Ozalla- Nkanu 36.37\% and 31.18\%; Akagbe Ugwu 37.50\% and $29.11 \%$ ).

The key informant interviews revealed that decisions concerning watersheds were mainly taken in the town community development union meetings and sometime in enlarged union meetings involving the youth and the women. The decisions reached were directed to the youth/women who were usually the executors of watershed programmes (Obiora, 2005). Entries in Table 5 confirmed that youth and women organizations were the agents of watershed maintenance in three of the communities e.g. Agu (85.75\% and $92.59 \%)$; Ozalla Nkanu (81.82\% and $72.73 \%$ ); Akagbe Ugwu $(87.50 \%$ and $79.17 \%)$ for youth and women organizations respectively.

The other three communities did not recognize government as managers and agents of watershed maintenance except in Oji urban. This might be because of the existence of government forestry project owned by the Nigerian coal corporation in the area

\section{Agents of participatory watershed management and maintenance in the communities}

Results in the Table 4 and 5 show the major stakeholders for watershed management and maintenance. With the exception of Oji Urban which had no stakeholder in watershed management, other communities like Achi-Agu, Ozalla Nkanu Akabge Ugwu had town community development unions $(70.99 \%)$ and family/clan heads $(66.42 \%)$ as their major stakeholders (Table 4). Youth organization $(53.71 \%)$ and women organization $(51.73 \%)$ were also stakeholders in watershed management in the communities. However, key informant interviews revealed that decisions concerning watersheds were mainly taken in the town development union meetings and sometimes in enlarged union meetings involving the youth and women. The decisions reached were directed to the youth/women who were usually the executors of watershed programmes (Obiora, 2005).

Entries in Table 5 confirmed that youth (63.65\%) and women $(61.12 \%)$ organizations were the agents of watershed maintenance in the communities. The other three communities did not recognize government as agent of watershed maintenance except in Oji Urban where $48.15 \%$ of the respondents reported government as agent of watershed maintenance. This could be as a result of the existence of government forestry project owned by the Nigerian Coal Corporation in the area.

It could be deduced from results in Table 4 and 5 that participatory watershed management approach was not applied in watershed management and maintenance in the communities. This was because not all the relevant stakeholders were given equal opportunity for participation. For instance, local NGOs, age grades, scientists/researchers, extension workers, policy makers and other relevant stakeholders needed to be involved in every aspect of the watershed projects. 
Table 4: Percentage distribution of stakeholders for watershed management in the communities

\begin{tabular}{|c|c|c|c|c|c|}
\hline \multirow[b]{2}{*}{ Watershed Managers* } & \multicolumn{4}{|c|}{ Watershed communities } & \multirow[b]{2}{*}{$\begin{array}{c}\text { Overall } \\
\%\end{array}$} \\
\hline & $\begin{array}{c}\text { Ezera } \\
\text { (Oji } \\
\text { Urban) } \\
n=27 \\
\%\end{array}$ & $\begin{array}{c}\text { lyi } \\
\text { Owerre } \\
\text { (Achi } \\
\text { Agu) } \\
\text { n= 27 } \\
\%\end{array}$ & $\begin{array}{c}\text { Ufam } \\
\text { (Ozalla } \\
\text { Nkanu) } \\
\mathrm{n=22} \\
\%\end{array}$ & $\begin{array}{c}\text { Nvene } \\
\text { (Akagbe } \\
\text { Ugwu) } \\
\text { n=24 } \\
\%\end{array}$ & \\
\hline $\begin{array}{l}\text { Town community } \\
\text { development union }\end{array}$ & 0.00 & 96.30 & 91.82 & 95.83 & 70.99 \\
\hline Family/ clan heads & 0.00 & 92.59 & 77.27 & 95.83 & 66.42 \\
\hline Age grade & 0.00 & 0.00 & 0.00 & 0.00 & 0.00 \\
\hline Youth organization & 0.00 & 74.67 & 81.82 & 58.33 & 53.71 \\
\hline Women organization & 0.00 & 66.67 & 77.73 & 62.50 & 51.73 \\
\hline Government & 0.00 & 0.00 & 0.00 & 0.00 & 0.00 \\
\hline Local NGOs & 0.00 & 0.00 & 0.00 & 0.00 & 0.00 \\
\hline Igwe's cabinet & 0.00 & 0.00 & 0.00 & 0.00 & 0.00 \\
\hline
\end{tabular}

Table 5: Percentage distribution of stakeholders for watershed maintenance

\begin{tabular}{|c|c|c|c|c|c|}
\hline \multirow[b]{2}{*}{$\begin{array}{l}\text { Agents of Watershed } \\
\text { Maintenance* }\end{array}$} & \multicolumn{4}{|c|}{ Watershed communities } & \multirow[b]{2}{*}{$\begin{array}{c}\text { Overall } \\
\%\end{array}$} \\
\hline & $\begin{array}{c}\text { Ezera (Oji } \\
\text { Urban) } \\
\mathbf{n}=\mathbf{2 7} \\
\%\end{array}$ & $\begin{array}{c}\text { Iyi } \\
\text { Owerre } \\
\text { (Achi } \\
\text { Agu) } \\
\text { n=27 } \\
\%\end{array}$ & $\begin{array}{c}\text { Ufam } \\
\text { (Ozalla } \\
\text { Nkanu) } \\
\mathrm{n}=22 \\
\%\end{array}$ & $\begin{array}{c}\text { Nvene } \\
\text { (Akagbe } \\
\text { Ugwu) } \\
n=24 \\
\%\end{array}$ & \\
\hline Government & 48.15 & 0.00 & 0.00 & 0.00 & \\
\hline $\begin{array}{l}\text { Town community } \\
\text { development union }\end{array}$ & 0.00 & 47.00 & 31.82 & 37.50 & 29.08 \\
\hline The family/clan heads & 0.00 & 22.22 & 18.18 & 20.83 & 15.31 \\
\hline $\begin{array}{l}\text { Traditional religion (gods } \\
\text { and goddess) }\end{array}$ & 0.00 & 29.63 & 54.55 & 58.33 & 35.63 \\
\hline Age grades & 0.00 & 37.04 & 22.27 & 33.33 & 23.16 \\
\hline Women organization & 0.00 & 92.59 & 72.73 & 79.17 & 61.12 \\
\hline Youth organization & 0.00 & 85.28 & 81.82 & 87.50 & 63.65 \\
\hline lgwe's cabinet & 0.00 & 0.00 & 0.00 & 0.00 & 0.00 \\
\hline
\end{tabular}




\section{Implications for Participatory Watershed Management Approach}

The problems of sustainability of watersheds in the communities studied could be ameliorated with the application of participatory watershed management approach. The injection of some experts in watershed management into the town community development unions to plan for the watersheds in the communities is expected to give a better result. According to the United States National Estuary Programmes, decision-making on the watersheds should be based on the best information and science available.Sound science provides objective information that informs debate, produces data on the status and trends of the watershed, and furnishes a basis for policies and programmatic decisions ( National Estuary Programme, 2005). These ingredients are lacking in the communities and the result is that the future sustainability of these watersheds is not assured.

In participatory watershed management approach all stakeholders participate in development processes and decisions. For instance stakeholders such as farmers, local government leaders, and representatives of local NGOs and/or researchers jointly discuss and decide about watershed planning and set priorities for taking up development tasks, such as trying out a technology or methodology in a new location. This is what is needed in the communities to ensure the sustainability of watersheds. Therefore the need for watershed extension workers is paramount so as to help in organizing and mobilizing required personnel for intervention. This can easily be achieved through capacity building. According to FAO (2006) continuing education process should be launched to increase the capacity of professionals, administrators and local stakeholders to understand and manage the inter-sectoral processes and approaches necessary for effective watershed management.

\section{Conclusion}

Based on the findings of the study, the following conclusions were made:

1. There exist challenges to sustainability of watersheds in rural communities of Enugu State because of unsustainable watershed practices like felling of trees, grazing of animal, excessive fuel wood exploitation, fishing with chemicals, farming very close to the watersheds, excavation activities etc.

2. The watershed rules and regulations in the communities only emphasized environmental sanitation but there were no rules and regulations to ensure sustainability of the watersheds.

3. Some sanctions for violators of watershed rules and regulations were perceived to be effective but did not address the issue of unsustainable practices.

4. The stakeholders for watershed management and maintenance were grossly inadequate and incapable of solving problems of sustainability of watersheds in the rural communities.

\section{Recommendations}

The following recommendations can ameliorate the problems of sustainability of watersheds in rural communities of Enugu State.

1. Participatory watershed management approach can help to solve the problem of sustainability of watersheds.

2. There is need for capacity building of all the stakeholders.

3. the is need to enlist the services of watershed extension workers to launch watershed extension education in the communities. 


\section{References}

Achim, S.; Steven, J.M.C. and lan, J. (2005). How much an ecosystem worth. Assessing the economic value of conservation. IUCN. The Nature Conservancy and the World Bank, Washington D.C.

Douglas, M., Considine, P. E. and Considine, G. D. (1989). Van Nostrands Scientific Encyclopedia: Seventh edition. Considine Vol. 11: 2993-3003.

Enwelu, I. A. (2007). The state and management of watersheds in Enugu State .Unpublished pre-Ph.D Seminar, Department of Agricultural Extension, University of Nigeria, Nsukka.

Fleming, B., Hufschmidt, M.M. and Hyman, E.L. (1982). Environmental and economic impacts of water conservation on a major reservoir project in Ecuador. In economic approaches to natural resources and environmental quality analysis. Dublin, Tycooly Int.

Food and Agricultural Organisation (FAO) (2006). The new generation of watershed management programmes and projects. FAO Forestry Paper 150. FAO Rome.

Huber, U.M.; Bugmann, H.K.M. and Reasoner, M.A. (eds.) (2005). Global change and mountain regions: An overview of current knowledge. Advances in Global Change Research, Vol. 23. Netherlands, Springer-Verlag.

IPCC (2001). Third Assessment Report. Intergovernmental Panel on Climate Change (IPCC).

Joshi, P.K., Tewari, L.; Jha, A. K. and Shuyani, R.L. (2003). Impact of watershed programme and people's participation. National Centre for Agricultural Economics and Policy Research (NCAP), New Delhi, India.

Kerr, J.; Pangare, G. and Pangare, V.L. (2002). Watershed development projects in India: An evaluation, Washington DC: International Food Policy Research Institute (IFPRI) (www.ifpri.org./pins/abstract/abstract127.htm).

N.E.P. (2005). Community-based watershed management: Lessons from the National Estuary Program (NEP): United States Environmental Protection Agency, Washington, D.C. 20460.

Obiora, C.J. (2005). The role of institutions in watershed management in Enugu State, Nigeria. Unpublished M.Sc Research Findings Seminar, Department of Agric. Extension, University of Nigeria, Nsukka.

Pitman, G.K. (2002). Bringing troubled waters. Assessing the World Bank Water Resources Strategy. World Bank Operations Department (OED) World, Bank, Washington, D.C. (http://www.WorldBank.org/oed).

Reddy, V.R.; Reddy, M.G.; Galab, S.; Sousson, J. and Baginski, O. S. (2004). Participatory watershed development in India: Can it sustain rural livelihoods? Development and change 35(2): 297-326.

Sherbinin, A. (1997). Water and population dynamics. Local approaches to a global challenges, IUCN \& PRB.

South Florida Water Management District (SFWMD) (2004a). Florida's Five Water Management District (http://www.sfwmd.gov.histo/3 5wmd.html)

Turton, C.; Coulter, J; Shah, A. and Farnagton (1998). Watershed development in India: Impact of the 1994 guidelines. A report prepared for Government of India (GOI) and DFID (New Delhi). London: ODI.

United State Environmental Protection Agency (US WPA) (2003). Surf your watershed (http://www.epa.gov/surf) US IPA.

Wani, P.; Sing, H. P.; Sreendevi T. K; Pathak, P.; Rego T. J; Shiferaw B.; and lyer S. R (2005). Farmer-participatory integrated watershed management. Adarsha watershed, Kothapally India. An innovative and upscalable approach. Case 7 part 3 case example series ICRISAT, India. 